\title{
Deploment of Characters and Entrepreneurship Through Gardening Activity in Social Science Learning
}

\author{
Ibdalsyah $^{1}$, SalatiAsmahasanah $^{2}$, Maemunah Sa'diyah $^{3}$ \\ ibdalsyah@fai.uika-bogor.ac.id ${ }^{1}$, salati@fai.uika-bogor.ac.id², maemunah@fai.uika-bogor.ac.id ${ }^{3}$ \\ Prodi Magister Ekonomi Syariah University of Ibn Khaldun, Indonesia ${ }^{123}$
}

\begin{abstract}
The purpose of this study is to describe the development of the character and entrepreneurship values in the learning of Social Science. This research method mixmethods is a research approach that combines or associates qualitative and quantitative forms. Data collection techniques through interview, observation, focus group discussion, questionnaire. The schools that became the location of the study were Al Hidayah, Nurul Iman, Misbahul Islam, and Mathlalul Anwar private Islamic Elementary Schools. The results of this study, through the gardening activities of teachers can explore the values of positive characters for students, among others, are grateful for God's favors, patience and entrepreneurial spirit, responsible, disciplined, cooperative, plant-loving attitude and environment, patience, social spirit, caring and respecting each other. And the teaching and learning process is more meaningful because students directly practice farming or gardening and entrepreneur.
\end{abstract}

Keywords: Character, Entrepreneurship, Gardening, Social Science

\section{Introduction}

The formulation of educational objectives contained in article 3 of Law No. 20 of 2003 concerning the following national education systems: National education functions to develop the ability and shape of dignified national character and civilization in order to educate the lives of the nation, aiming to develop the potential of students to become faithful and fearful people of God, healthy, knowledgeable, capable, creative, independent and become a democratic and responsible citizen.

Based on the formulation of the national education objectives above, we can see a number of competencies that are expected to emerge after the education process. The competency in question is a number of abilities that can be mastered and shown by students as a result of the educational process[1]. The competencies that are expected to emerge as a result of the educational process which referred to in the law are the development of the potential of students to become faithful and fearful people of God, having the character of starting, being healthy, knowledgeable, capable, creative, independent, and being citizens democratic and responsible.[2]

The aim of national education is to become a reference in the development of social science goals. The aim of social science according to James Banks includes a range of abilities 
that include knowledge, skills in academic terms and skills and the development of character values. In addition, Schunke added it to the development and formation of citizenship. Thus the competencies developed in social science include the ability to develop aspects of intellectualism and the development of social skills needed by students in community life.[3]

But the problem found by researchers in the field is interest in learning, students' abilities and skills in social studies learning are still very minimal. The quality of the way teachers teach is also still conventional, which tends to be teacher-centered, so that teaching and learning activities are less attractive to students.[4] Then, the learning that has been carried out also has not utilized the environment as a learning media, students are also still focused on cognitive alone without developing social and other aspects. Whereas the goal of social studies education is "fostering students to be good citizens, who have the knowledge, skills and social care that is useful for themselves and for the community and the country" whereas in detail they formulate the objectives of social studies education oriented to the behavior of students, namely: (1) knowledge and understanding, (2) attitudes to learning life, (3) social values and attitudes, (4) skills.[5]

For social science learning, the five steps of learning are related to primary sources of social studies, those are the community and the environment. With this learning process, the application of what they learn in the community and make the community as a learning resource.

In the implementation of cultivating environment-based learning in elementary schools, one of them is through school garden activities.

The general objectives of environmental education according to UNESCO in the Tbilisi conference [6] are: (1) to help explain the issue of concern and care about the interrelationships between economy, social, the politic and ecology in cities and in rural areas; (2) to provide opportunities for everyone to develop the knowledge, values, attitudes, commitments, and abilities needed to protect and improve the environment, and (3) to create new patterns of behavior for individuals, groups and society as a whole towards environment. The objectives to be achieved include aspects of: (1) knowledge, (2) attitude, (3) care, (4) skills, and (5) participation.

In this regard, in the results of the Afandi's study [7] argues that the exploitation of the earth by humans imposes environmental damage that threatens the habitat of humans and other living things on earth. Through environmental education, it is expected to grow human conscious attitude to safeguard and preserve the environment. Primary school is a means of education in teaching environmental education that is very appropriate, by teaching environmental awareness as early as possible to the younger generation.

\section{Literacy Review}

\subsection{Concept of Gardening Learning}

The environment as a learning media is similar to what is conveyed by Slameto (2003: 2) "Learning is a business process carried out by a person to obtain a new behavior change as a whole, as a result of his own experience in interaction with his environment".

Hamalik [8] in his theory "Back to Nature" shows how important the influence of nature is on the development of students. With gardening learning in school, children understand that their original food from the earth and their diet has become healthier. Some studies even show that students are able to influence their family's diet. "Parents say children eat lots of fruits and 
vegetables, and they insist on eating vegetables and fruit at home (Peixinho, 2016). Through the school garden activities can improve students' naturalistic intelligence that they can explore themselves and learn many things from the natural environment. Likewise the results of Marheni's research [9] that the use of school gardens makes learning more meaningful because students are involved directly so that students can construct their own knowledge, that school gardens can be used as natural laboratories in natural science learning, one of which can improve students' knowledge of the scientific name of plants.[10]

According to Kellert (2005) playing in nature, especially in critical periods from childhood, is a very important time in developing creativity, problem solving, intellectual and emotional development [11].

\subsection{Definition of Entrepreneur}

Entrepreneur is someone who does entrepreneurial activities by recognizing new products, determining new production methods starting from preparing operations for the procurement of new products and marketing them and regulating their operating capital. Entrepreneurship is one of the businesses run by private companies, including cooperatives or joint ventures [12].

Someone who does business or work in the field of entrepreneurship must have the courageous nature in facing challenges and risks, such as loss or cheating by consumers, even unpredictable losses such as natural disasters, losses due to wrong decisions or policies, all possibilities worst even though he has to face and pass, the entrepreneur must learn a lot from experience, face various obstacles and difficulties, that's where patience and tenacity are required until what is expected in the business is achieved, namely big profits.[13]

The aim of entrepreneurship is to get profit, the breadth spread in the universe, meaning that an entrepreneur must be able to explore the potential and process the potential into a reality that is useful and beneficial. Entrepreneurs must be able to bring change to reach the sustenance promised by God for His servants in this world to be sought by doing various forms of effort. One effort that can be done is by making a sale and purchase transaction (albay '). Allah has justified buying and selling and forbid someone to commit usury, Allah said: "and Allah has justified the sale and purchase and forbid usury". Surah al-Baqarah: 275. In carrying out a business or business, the Messenger of Allah forbade using vanity methods such as gambling, cheating, manipulation, deprivation or forcibly taking threats and marketing threats.

According to language, buying and selling is the exchange of goods, whether in the form of material property or immaterial, business is a commercial business, trading, trading whose main orientation is to get profit. In terms, buying and selling is: "A contract to exchange goods, either with goods or with money and there was a transfer of ownership of the goods", (Mustafa al-Khin and Mustafa al-Bugha, al-Fiqh al-Manhaji, juz 3 things 5)

This is also called barter, when exchanging these items using the medium of exchange, namely dinar, dirham, dollars or money, the term buying and selling or al-bai is accepted. Buying and selling or al-bai 'is one of the efforts to get the gift of God in this world, this effort is part of worship that can bring God's grace and forgiveness.

Entrepreneurs include four important elements, namely: Power of thought (cognitive), skills (psychomotor), mental attitude (affective) and alertness or intuition [12].

Childhood experience doing entrepreneurship activities will be a big capital psychologically, the character will be formed by the difficulties and challenges faced to be mental strength when plunging into the world of entrepreneurship, he will become an innovative person, not 
afraid to face difficulties. One of the entrepreneur's activities is through learning buying and selling from the results of the importance of gardening activities in schools.[12]

\section{Methode}

This research method is mix methods or combination research. According to Creswell [14] mix-methods are research approaches that combine or associate qualitative and quantitative forms. Whereas according to Johnson and Cristensen[4]. Mix methods or combination research methods are approaches in research that combine or connect between qualitative and quantitative research methods (including philosophical foundation, use of approaches and combine both approaches in research). So that from the various definitions of the experts above it can be concluded that the Mix-methods research is a research that combines or combines qualitative and quantitative research approaches. Data collection techniques through interview, observation, focus group discussion, questionnaire. In the Mix Methods research, data analysis can be done in several ways, those are:

1. Concurrent mixed analysis: analysis of qualitative and quantitative data

2. Gradual qualitative-quantitative analysis: qualitative data analysis followed by qualitative data collection and analysis as affirmation

3. Gradual quantitative-qualitative analysis: qualitative data analysis followed by collecting qualitative data analysis

The schools that were the location of the study were Al Hidayah, Nurul Iman, Misbahul Islam, and Mathlalul Anwar private Islamic Elementary Schools.

\section{Results and Discussion}

The results and discussion of this study include:

\subsection{ALhidayah private Islamic Elementary School}

The results of the student character evaluation during the agro-garden vegetable education activities are as follows:

1) Beginning to be seen, is respect, responsibility, discipline, cooperation, grateful for God's favors, care

2) Start developing, is love of plants and environment, patience, social spirit, and entrepreneurial spirit.

\subsection{Nurul Iman private Islamic Elementary School}

The results of the assessment of students' attitudes during the agro-garden vegetable education activities are as follows:

1) Beginning to be seen, is to be grateful for God's favors, patience and entrepreneurial spirit.

2) Starting to develop, is responsible, disciplined, collaborative, loving attitude to plants and environment, preparedness, social spirit, and caring. 
3) Cultivating, is mutual respect.

\subsection{Mathlaul Anwar private Islamic Elementary School}

The results of the assessment of students' attitudes during the agro-garden vegetable education activities are as follows:

1) Beginning to be seen, is respect, love of plants and environment, patience, caring, patience and entrepreneurial spirit.

2) Starting to develop, is responsible, disciplined, cooperative, grateful for Allah's favor, social spirit.

\subsection{Misbahul private Islamic Elementary School}

From the results of the recapitulation of students when the activities of the vegetable garden agro education are as follows;

1) Start to look, is responsible

2) Start developing, appreciating, discipline, love of plants and environment, patience, caring, social spirit and entrepreneurial spirit.

3) Cultivating, is cooperation, grateful for God's favor.

We can conclude in the following graph

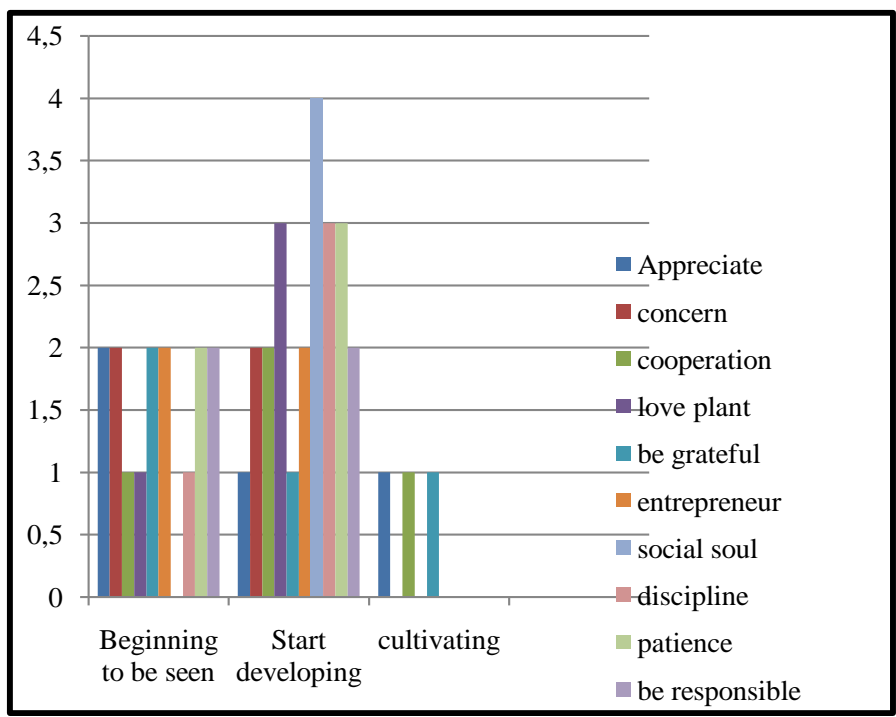

Figure 1.1 Graph of Character Assessment in gardening learning 
From the graphs of observation the learning activities of vegetable gardens in the four research locations can be concluded for the characters that are starting to appear, in the first position of the character of entrepreneur, thanking God for His creation, caring attitude, and mutual respect, patience and responsibility. Then in the second position the characters that began to look are loving plants, discipline and cooperation. Start developing is the first position, social spirit and second, the character that appears is the attitude of loving plants. Discipline and patience. The third position character is entrepreneurial spirit, cooperation, responsibility and care. And the fourth position is gratitude and mutual respect. And what is already entrenched is the character of gratitude, cooperation and mutual respect

Through gardening activities students carry out entrepreneur activities through buying and selling vegetables produced at school. So that the teacher can explore the values of positive characters for students, among others, is to be grateful for God's favors, patience and entrepreneurial spirit, responsible, disciplined, cooperative, plant-loving attitude and environment, patience, social spirit, caring and respecting each other. Value is a standard of behavior, beauty, efficiency or meaning that someone supports and maintains [4]. Besides that the teaching and learning process is more meaningful because students not only understand theoretically the steps of farming and how to care for plants, but also students practice directly. The teacher gives an example directly by using material tools and school garden locations that have been prepared and provide an example to students to care about the plants by caring for them. This is consistent with Jully Cheung's statement that educating is not just advice, because being successful is giving an example with good deeds, according to what he said [13].

This entrepreneurial activity to cultivate as well as mental attitude to move forward will give birth to positive and responsible attitudes and actions, those are:

1. Deft attitude and not procrastinating work, for this person the opportunity is something very expensive, it will hurt someone who has a pattern of thinking likes to delay work, opportunities sometimes do not come twice, when there is a chance, there is free time, health too support, then immediately seize the opportunity, use as much as possible so that there is no regret behind the day.

2. Become responsive, someone who is responsive to opportunities will get surprising and unexpected results.

3. Honest and responsible. This honest attitude will lead to calmness in work, no negative thoughts appear to lie and cheat, a calm heart will make the mind open, the work that becomes trustworthy can be done with a sense of responsibility, this sense of responsibility will be more motivating someone in carrying out his job mandate.

4. Caution, this trait is the deepest intuition of an entrepreneur based on life experience. Many people get knowledge and personal maturity caused by experience, a lot of socializing with the community, so that a sense of responsibility is getting stronger, not easy to give up in completing their responsibilities.

Entrepreneurship does not just happen, but must go through a long process. Starting early, children are very easily affected by what he sees and what he hears. Hearing and vision are the entrance to science, children will become accustomed and imprint on the heart and mind of the child, there is a process of education and learning. Child education must include knowledge that supports children's lives and is related to child development. When this entrepreneurship is introduced to children, this learning will imprint on them, will shape the child's personality. 
Rasulullah SAW started entrepreneurship when he was 12 years old until he was appointed as Rasulullah SAW. [3].

\section{Conclusion}

This research was carried out at Al Hidayah, Nurul Iman, Misbahul Islam, and Mathlalul Anwar private Islamic Elementary schools located in Taman Sari Sub district. The results of this study, through the gardening activities of teachers can explore the values of positive characters for students, among others, are grateful for God's favors, patience and entrepreneurial spirit, responsible, disciplined, cooperative, plant-loving attitude and environment, patience, social spirit, caring and respecting each other. And the teaching and learning process is more meaningful because students directly practice farming or gardening and entrepreneur.

\section{Refrence}

[1] 12) Sugiyono, Metode Penilaian Pendidikan (Pendekatan Kuantitatif, Kualitatif dan R/D. Bandung: Alfabeta., 2007.

[2] J. Siraj-Baltchford, K. , Smith, and I. . Samuelsson, Education for sustainable development in the early years. Copenhagen: WHO Regional Office for Europa, 2010.

[3] Antonio and M. Syafii, Muhammad SAW the Super Leader Super Manager. ProLM Center : Jakarta, 2007.

[4] N. . 13) Sukmadinata, Metode Penelitian Pendidikan. Bandung: PT Remaja Rosda Karya, 2010.

[5] 10) Sangit, “Analisis Data Kualitatif,” 2011. [Online]. Available: Http//:sangit26.blogspot.com. .

[6] U. 9) Sadulloh, Pedagogik. Bandung: Cipta Utama., 2007.

[7] M. A. 8) Nuryanto, "Kritik Budaya Akademik di Pendidikan Tinggi," J. Soc. Media, vol. 1, pp. 35-42, 2017.

[8] Ekayanti and N. I. W. Dkk, "Kebun Sekolah sebagai Laboratorium Alami untuk Pembelajaran IPA: Mengenakan nama ilmiah tanaman dalam kehidupan sehari-har," J. Suluh Pendidik., vol. 16, pp. 51-55, 2018.

[9] Marheni, "Pembelajaran sains Tumbuhan Berbasis Etnobotani Terintegrasi Tanaman Obat,” J. Suluh Pendidik., vol. 15, pp. 169-175, 2017.

[10] Hakam. and K. Abdul, Pengantar Pendidikan Nilai. 2007.

[11] C. (Ed). Charles, Children's contact with the outdoors and nature a focus on educational settings.C£NN. 2010.

[12] Yusanto and M. I. Dkk, Menggagas Bisnis Islami. Jakarta : Gema Insani Press.

[13] P. Fathurrahman, Strategi Belajar Mengajar. Bandung:PT Rafika Aditama.

[14] L. Asmawati, Pembelajaran PAUD. Bandung : PT. Remaja Rosdakarya., 2014. 
UUD No.12 tahun 2012 pasal 1 ayat 9 